\title{
Helping hands: A cluster randomised trial to evaluate the effectiveness of two different strategies for promoting hand hygiene in hospital nurses
}

Anita Huiš, Lisette Schoonhoven, Richard Grol, George Borm, Eddy Adang, Marlies Hulscher and

Theo van Achterberg

\begin{abstract}
Background: Hand hygiene prescriptions are the most important measure in the prevention of hospital-acquired infections. Yet, compliance rates are generally below 50\% of all opportunities for hand hygiene. This study aims at evaluating the short- and long-term effects of two different strategies for promoting hand hygiene in hospital nurses.

Methods/design: This study is a cluster randomised controlled trial with inpatient wards as the unit of randomisation. Guidelines for hand hygiene will be implemented in this study. Two strategies will be used to improve the adherence to guidelines for hand hygiene. The state-of-the-art strategy is derived from the literature and includes education, reminders, feedback, and targeting adequate products and facilities. The extended strategy also contains activities aimed at influencing social influence in groups and enhancing leadership. The unique contribution of the extended strategy is built upon relevant behavioural science theories. The extended strategy includes all elements of the state-of-the-art strategy supplemented with gaining active commitment and initiative of ward management, modelling by informal leaders at the ward, and setting norms and targets within the team. Data will be collected at four points in time, with six-month intervals. An average of 3,000 opportunities for hand hygiene in approximately 900 nurses will be observed at each time point.
\end{abstract}

Discussion: Performing and evaluating an implementation strategy that also targets the social context of teams may considerably add to the general body of knowledge in this field. Results from our study will allow us to draw conclusions on the effects of different strategies for the implementation of hand hygiene guidelines, and based on these results we will be able to define a preferred implementation strategy for hospital based nursing.

Trial registration: The study is registered as a Clinical Trial in ClinicalTrials.gov, dossier number: NCT00548015.

\section{Background}

Hospital-acquired infections (HAIs) are a serious and persistent problem throughout the world. They are burdensome to patients, complicate treatment, prolong hospital stay, increase costs, and can be life threatening [1,2].

Micro-organisms on the hands of healthcare workers contribute to the incidence of infections in patients $[3,4]$. Therefore, hand hygiene prescriptions are widely

\footnotetext{
* Correspondence: a.huis@iq.umcn.nl

Scientific Institute for Quality of Healthcare, Radboud University Nijmegen Medical Centre Nijmegen, The Netherlands
}

accepted as the most important measure in the prevention of HAIs [5-11]. Unfortunately, numerous studies over the past few decades have demonstrated that healthcare workers still perform hand hygiene on average less than 50 percent of the times required [12-14]. Thus, current practices deviate from the goal of providing safe hospital care aimed at prevention of adverse events, morbidity, and mortality.

In their review on approaches for transferring evidence to practice, Grol and Grimshaw [15] used a case study looking at strategies to improve hand hygiene in 
hospital settings. They concluded that plans for improvement of current performance should be based on barriers and facilitators for change. Regarding hand hygiene, they concluded that changing behaviour is possible, but this change generally requires 'a comprehensive plan with strategies at different levels (professional, team, patient, and organisation) to achieve lasting changes in hand hygiene routines.'

Traditionally, implementation strategies have focussed on professionals-the individual level-or addressed structural work context-the organisational level. Teamdirected strategies are hardly studied $[15,16]$. Yet, teamdirected strategies could be valuable as healthcare workers (especially nurses) usually work in teams. Performing and evaluating an implementation strategy that also targets the social context of teams may considerably add to the general body of knowledge in this field.

\section{Aims and objectives}

The aim of this study is to test two implementation strategies in inpatient wards to improve nurses' compliance with hand hygiene prescriptions and to compare the short-term and sustained effects of these innovative strategies. The objectives of this project are threefold: to improve compliance with guidelines for hand hygiene in nurses; to assess the cost effectiveness of both strategies; and to gain insight into determinants of success or failure of the strategies.

\section{Scientific hypothesis}

Our hypothesis is that an extended strategy, using additional implementation activities based on social influence and leadership, will be more effective in increasing hand hygiene compliance rates compared to a state-ofthe-art strategy, mainly addressing the individual and organisational level.

\section{Methods}

\section{Quality improvement strategies}

The state-of-the-art strategy is based on current evidence from literature on hand hygiene compliance $[1,15]$. Short-term effectiveness of this strategy is wellestablished in several studies and settings $[16,17]$. The strategy includes: education for improving relevant knowledge and skills; reminders for supporting the transfer from a positive intention to the actual performance of hand hygiene; feedback as a means to provide insight into current hand hygiene behaviour and to reinforce improved behaviour; and screening for adequate hand hygiene products and adequate facilities. The extended strategy also contains activities based on social influence in groups and leadership. This strategy largely draws from relevant theories and general evidence to support these theories [18-26]. The extended strategy includes all of the above elements of the state-of-the-art strategy as well as: gaining active commitment and initiative of ward management; modelling by informal leaders at the ward; and setting norms and targets within the team. Table 1 shows the operationalisation of both strategies.

\section{Study design}

The study will have a stratified cluster randomised trial design. In a cluster randomised trial, groups of individuals rather than individuals are randomised [27]. Cluster randomisation using wards as the unit of allocation reduces contamination between groups [28]. In our study, the quality improvement strategies involved the entire team of nurses and not individual nurses on nursing wards. Therefore, nurses within the same ward were considered to be a cluster.

Data will be collected for a six-month reference period-no strategy for promoting hand hygiene-prior to the trial (T1 and T2). After data collection for this reference period, randomisation to either the state-ofthe-art strategy or the extended strategy will take place. Strategies will be delivered during a second period of six months. Follow-up measurements will take place directly after strategy delivery (T3) and at six months after the end of strategy delivery (T4). Because the extended strategy consists of the state-of-the-art strategy supplemented with team-directed social influence approaches, randomisation of wards to each of the strategies is feasible. Our study design is illustrated in figure 1.

\section{Setting and participants}

The study will be performed in three hospitals: one university medical centre and two general hospitals. In a fourth (non participating) hospital, we will test the instruments and observer variability. Within the hospitals, all inpatient wards $(n=60)$, will participate in the study.

After completing baseline measurements of the reference period, wards will be randomly assigned to either the state-of-the-art strategy group $(\mathrm{n}=30)$, or the extended strategy group $(\mathrm{n}=30)$. The randomisation of the wards will be stratified for type of ward to minimize differences in ward characteristics over the strategies. We will randomise surgical wards, internal medicine wards, intensive care units, and paediatric wards.

\section{Parameters, instruments, and analysis}

To evaluate the effectiveness and efficiency of the strategies, we will use effect parameters and process parameters. First, we describe the evaluation of hand hygiene compliance and team climate. Second, the economic evaluation regarding costs and health effects. 
Table 1 Description implementation strategies

\begin{tabular}{|c|c|}
\hline State-of-the-art strategy & Extended strategy \\
\hline Education & All elements of the state-of-the-art strategy \\
\hline $\begin{array}{l}\text { Distribution of educational material/written information (leaflet) about } \\
\text { hand hygiene }\end{array}$ & - Education, reminders, feedback, facilities and products \\
\hline - The importance of hand hygiene & Setting norms and targets within the team \\
\hline - Misconceptions about alcohol-based hand disinfection & $\begin{array}{l}\text { - Three interactive team sessions that includes goal setting in hand } \\
\text { hygiene performance at group level }\end{array}$ \\
\hline - Theory and practical indications for the use of hand hygiene & $\begin{array}{l}\text { - Analysis of barriers and facilitators to determine how they could best } \\
\text { adapt their behaviour in order to reach their goal }\end{array}$ \\
\hline Website http://www.gewoonhandenschoon.nl & $\begin{array}{l}\text { - Nurses address each other in case of undesirable hand hygiene } \\
\text { behaviour }\end{array}$ \\
\hline - Educational material/written information about hand hygiene & Gaining active commitment and initiative of ward management \\
\hline - Knowledge quiz & - Ward manager designates hand hygiene as a priority \\
\hline - Reward for the nursing ward with the most visitors to the website & - Ward manager actively supports team members and informal leaders \\
\hline Educational sessions on prevention of hospital acquired infections & $\begin{array}{l}\text { - Ward manager discusses hand hygiene compliance rates with team } \\
\text { members }\end{array}$ \\
\hline $\begin{array}{l}\text { - Launching hospital wide campaign with practical demonstrations of } \\
\text { hand hygiene }\end{array}$ & Modeling by informal leaders at the ward \\
\hline Reminders & - Informal leaders demonstrate good hand hygiene behaviour \\
\hline $\begin{array}{l}\text { - Distribution of posters that emphasized the importance of hand } \\
\text { hygiene, particularly alcohol-based hand disinfection }\end{array}$ & $\begin{array}{l}\text { - Informal leaders models social skills in addressing behaviour of } \\
\text { colleagues }\end{array}$ \\
\hline - Interviews and messages in newsletters or hospital magazines & $\begin{array}{l}\text { - Informal leaders instruct and stimulate their colleagues in providing } \\
\text { good hand hygiene behaviour }\end{array}$ \\
\hline \multicolumn{2}{|l|}{ - General reminders by opinion leaders/ward management } \\
\hline \multicolumn{2}{|l|}{ Feedback } \\
\hline \multicolumn{2}{|l|}{$\begin{array}{l}\text { - Bar charts of hand hygiene rates of every nursing ward will be sent to } \\
\text { the ward manager twice }\end{array}$} \\
\hline \multicolumn{2}{|l|}{ - Comparison ward performance and hospital performance } \\
\hline \multicolumn{2}{|l|}{ Facilities and products } \\
\hline - Screening and if necessary adapt products and appropriate facilities & \\
\hline
\end{tabular}

Finally, we describe the assessment of the actual implementation of the strategies and the evaluation of barriers and ward structure.

\section{Effect evaluation: hand hygiene compliance}

Table 2 presents the effect parameters and instruments. The primary effect parameter for this study is the percentage of opportunities at which hand hygiene is performed by the nurses according to the National Guideline 'Handhygiene' of the Working group Infection Prevention (WIP) and the WHO Guidelines on Hand Hygiene in Healthcare $[29,30]$. The indications that create an opportunity-a required moment-for hand hygiene are listed in Table 3. Hand hygiene is operationalised as 'hand washing with either plain soap and water' or 'hand disinfection through the use of an alcohol-based hand rub solution.'

Other effect parameters are the presence of jewelry (ring, watch, or other jewelry) and whether the nurses wear long-sleeved clothes under their short-sleeved uniforms. We will observe compliance by using a Hand Hygiene Monitoring Tool adapted from the WHO (additional file 1). The observer will register each opportunity in a corresponding column block, note all of the applicable indications and whether hand hygiene is performed by hand disinfection or hand washing or is missed.

\section{Data collection}

At each point in time, an average of 3,000 opportunities for hand hygiene in approximately 900 nurses will be observed. We will use direct, but unobtrusive observation because this is considered the gold standard and the most reliable method for assessing compliance rates [1,31-33]. At the beginning of each observation period, nurses will be informed that the observers are conducting research on medication errors and other patient safety issues, but not that hand hygiene will be monitored. Observers will conduct their observations at times with a high density of care, mostly during the morning shifts. Observers will be blinded for the strategies delivered to the wards under observation.

\section{Observer variability}

For each observation period, we will train 10 student nurses, all completing their nursing education and 


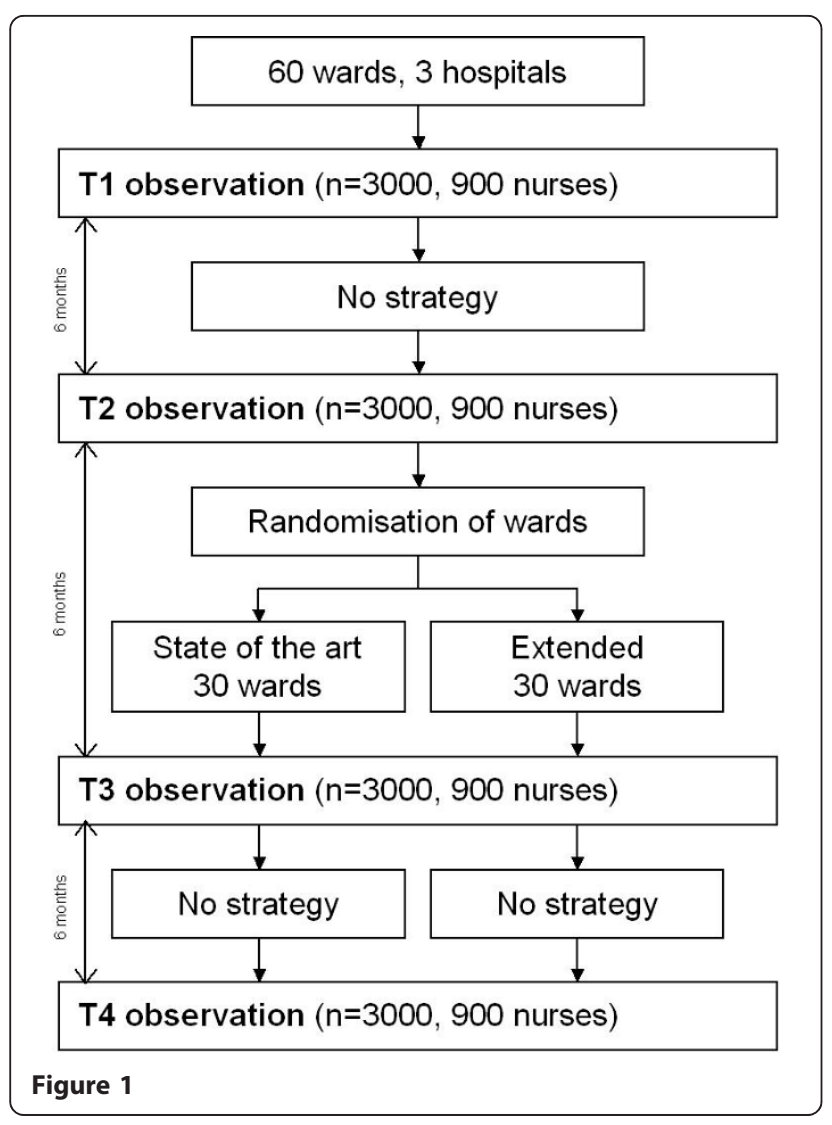

experienced in patient care, as well in collecting data. All student nurses will participate in a two-day training course on understanding the indications for hand hygiene during patient care. They will also learn to apply the observation method and to use the data collection form. Before conducting the observation sessions, the observations by the student nurses will be validated. Visual examples of patient care episodes will be presented, and the students will score related hand hygiene opportunities. Then, we will compare the results of the students and discus discordant notifications. Subsequently, we will undertake parallel monitoring sessions in a non-participating hospital. Every student nurse will perform twenty observations jointly with an experienced observer.

We will use a three-step approach to compare the concordance between the observer and the experienced observer. First, we will calculate the concordance between 'the number of recorded hand hygiene opportunities' of the student nurse and the experienced observer. Then, we will calculate the concordance between 'the number of recorded hand hygiene indications' of both observers. Finally, we will calculate the concordance between 'the number of recorded actions.' The Wilcoxon rank test will be used to detect differences between the student nurses and experienced observer.

Table 2 Parameters and instruments

\begin{tabular}{|c|c|c|}
\hline $\begin{array}{l}\text { Effect } \\
\text { parameter }\end{array}$ & Description & Instruments \\
\hline $\begin{array}{l}\text { Hand hygiene } \\
\text { compliance } \\
\text { Other } \\
\text { parameters }\end{array}$ & $\begin{array}{l}\text { The percentage of opportunities at which hand hygiene was performed according to } \\
\text { the National Guideline 'Handhygiene' of the Working group Infection Prevention } \\
\text { (WIP) and the WHO Guidelines on Hand Hygiene in Healthcare } \\
\text { The percentage of presence of jewelry and long-sleeved clothes }\end{array}$ & Hand hygiene monitoring tool \\
\hline Team Climate & $\begin{array}{l}\text { Dimensions 'participation safety, ' task orientation,' support for innovation,' and } \\
\text { 'interaction.' }\end{array}$ & Team Climate Inventory \\
\hline $\begin{array}{l}\text { Costs and health } \\
\text { effects }\end{array}$ & $\begin{array}{l}\text { Comparing resource consumption and HAls rate between the two implementation } \\
\text { strategies }\end{array}$ & $\begin{array}{l}\text { Activity-based costing; } \\
\text { Decision analysis }\end{array}$ \\
\hline $\begin{array}{l}\text { Process } \\
\text { parameter }\end{array}$ & Description & Instruments \\
\hline \multirow[t]{2}{*}{$\begin{array}{l}\text { Performance of } \\
\text { the strategies }\end{array}$} & $\begin{array}{l}\text { State-of-the-art strategy - Knowledge - number of nurses that completed the } \\
\text { knowledge quiz, presence of instruction leaflets. - Reminders - check of presence of } \\
\text { posters. - Performance feedback - actual delivery of performance feedback to team } \\
\text { members. }\end{array}$ & $\begin{array}{l}\text { Survey, direct observations; systematic } \\
\text { registration of time and meeting minutes }\end{array}$ \\
\hline & $\begin{array}{l}\text { Extended strategy - Coaching of ward management- number of coaching sessions, } \\
\text { total time spent on coaching, topics dealt with, managers evaluations of coaching. - } \\
\text { Coaching of informal leaders - number of coaching sessions, total time spent on } \\
\text { coaching, topics dealt with, informal leaders evaluations of coaching. - Team } \\
\text { discussions for norm- and target setting - number of nurses attending per ward, time } \\
\text { investment per ward, actual norms and targets decided on, nurses' evaluations of } \\
\text { team discussions }\end{array}$ & \\
\hline $\begin{array}{l}\text { Barriers to } \\
\text { change }\end{array}$ & $\begin{array}{l}\text { Including determinants like awareness, knowledge, reinforcement, control, social } \\
\text { norms, leadership, and facilities }\end{array}$ & Barrier questionnaire \\
\hline Ward structure & $\begin{array}{l}\text { Information about existing structures and resources like actual presence of facilities, } \\
\text { workload, nurse-bed ratio -under-staffing and support from the management }\end{array}$ & Ward structure questionnaire \\
\hline
\end{tabular}


Table 3 Observed indications for hand hygiene

\begin{tabular}{|c|c|c|c|c|}
\hline $\begin{array}{l}\text { Indication } \\
\text { for hand } \\
\text { hygiene }\end{array}$ & When & Transmission risk & $\begin{array}{l}\text { Major targeted } \\
\text { negative } \\
\text { infectious } \\
\text { outcome }\end{array}$ & Examples \\
\hline $\begin{array}{l}\text { Before an } \\
\text { aseptic task }\end{array}$ & $\begin{array}{l}\text { Directly before } \\
\text { performing an } \\
\text { aseptic task }\end{array}$ & $\begin{array}{l}\text { Hand transmission of micro-organisms } \\
\text { from any surface (including the patient } \\
\text { skin) to a site that would facilitate } \\
\text { invasion and infection }\end{array}$ & $\begin{array}{l}\text { Endogenous or } \\
\text { exogenous } \\
\text { infection of the } \\
\text { patient }\end{array}$ & $\begin{array}{l}\text { Giving an injection. Insertion and care of } \\
\text { intravenous catheters. Blood draws. } \\
\text { Administering intravenous medication. } \\
\text { Endotracheal suction }\end{array}$ \\
\hline $\begin{array}{l}\text { From } \\
\text { contaminated } \\
\text { body site to } \\
\text { another body } \\
\text { site }\end{array}$ & $\begin{array}{l}\text { Directly after } \\
\text { completing task } \\
\text { (whether gloved or } \\
\text { ungloved) }\end{array}$ & $\begin{array}{l}\text { Hand exposure to patient's contaminated } \\
\text { body sites and fluids potentially } \\
\text { containing blood-borne or other } \\
\text { pathogens }\end{array}$ & $\begin{array}{l}\text { Infection of the } \\
\text { HCW } \\
\text { by patient blood } \\
\text { borne } \\
\text { pathogens }\end{array}$ & $\begin{array}{l}\text { Drawing blood and then adjusting the } \\
\text { infusion drop count. Handle wound, mucous } \\
\text { membrane, and body fluids. After oral care }\end{array}$ \\
\hline $\begin{array}{l}\text { After touching } \\
\text { the patient }\end{array}$ & $\begin{array}{l}\text { Directly after } \\
\text { leaving the patient } \\
\text { when the patient } \\
\text { was touched }\end{array}$ & $\begin{array}{l}\text { Hand transmission of micro-organisms } \\
\text { from the patient flora to other surfaces in } \\
\text { the healthcare setting }\end{array}$ & $\begin{array}{l}\text { Dissemination of } \\
\text { patient flora to } \\
\text { the rest of the } \\
\text { healthcare } \\
\text { environment and } \\
\text { infection of other } \\
\text { patients or HCWs }\end{array}$ & $\begin{array}{l}\text { After skin contact with the patient. Bathing, } \\
\text { change position or lifting a patient. Taking a } \\
\text { pulse or blood pressure. Shaking hands }\end{array}$ \\
\hline $\begin{array}{l}\text { After taking } \\
\text { care of an } \\
\text { infected/ } \\
\text { colonized } \\
\text { patient }\end{array}$ & $\begin{array}{l}\text { Directly after } \\
\text { leaving the } \\
\text { patient's room }\end{array}$ & $\begin{array}{l}\text { Hand transmission of micro-organisms } \\
\text { from the patient flora to other surfaces in } \\
\text { the healthcare setting }\end{array}$ & $\begin{array}{l}\text { Dissemination of } \\
\text { patient flora to } \\
\text { the rest of the } \\
\text { healthcare } \\
\text { environment and } \\
\text { infection of other } \\
\text { patients or HCWs }\end{array}$ & $\begin{array}{l}\text { Contact with any patient know to be } \\
\text { infectious/isolated (eg. MRSA) }\end{array}$ \\
\hline $\begin{array}{l}\text { After use of } \\
\text { gloves }\end{array}$ & $\begin{array}{l}\text { Directly after } \\
\text { removing gloves }\end{array}$ & $\begin{array}{l}\text { Hand transmission of micro-organisms } \\
\text { from the skin of the HCW 's to other } \\
\text { surfaces in the healthcare setting }\end{array}$ & $\begin{array}{l}\text { Dissemination of } \\
\text { patient flora to } \\
\text { the rest of the } \\
\text { healthcare } \\
\text { environment and } \\
\text { infection of other } \\
\text { patients or HCWs }\end{array}$ & Wearing gloves high-risk contacts \\
\hline $\begin{array}{l}\text { After contact } \\
\text { with patient } \\
\text { surroundings }\end{array}$ & $\begin{array}{l}\text { After completing } \\
\text { the task and before } \\
\text { contacting another } \\
\text { patient }\end{array}$ & $\begin{array}{l}\text { Hand transmission of micro-organisms } \\
\text { from the patient flora to other surfaces in } \\
\text { the healthcare setting }\end{array}$ & $\begin{array}{l}\text { Dissemination of } \\
\text { patient flora to } \\
\text { the rest of the } \\
\text { healthcare } \\
\text { environment and } \\
\text { infection of other } \\
\text { patient or HCWs }\end{array}$ & $\begin{array}{l}\text { Touching the patient's environment like bed, } \\
\text { table, blanket, clothes. After contact with } \\
\text { medical equipment in the immediate vicinity } \\
\text { of the patient }\end{array}$ \\
\hline
\end{tabular}

\section{Statistical analysis}

The effects of the two strategies will be evaluated on an intention-to-treat basis by comparing the hand hygiene compliance rates in the two study groups after performing the strategies with the compliance rates at the end of the reference period. The differences between the two strategies will be evaluated by comparing the hand hygiene compliance rates of both groups after performing the strategies. Multilevel analysis will be applied to compensate for the clustered nature of the data (compliance is clustered within healthcare workers who are clustered within units) using mixed linear modelling techniques, including the following covariates: ward (random effect), HCW (random effect, nested within ward), institution and the baseline results of the wards. The relevance of nurses' gender, ward specialism, and type of hand hygiene opportunity will also be explored by performing sub group analyses.

\section{Sample size}

The state-of-the-art implementation strategy should be able to improve hand hygiene compliance with $15 \%$ in the short term [1]. We assume an added effect of $10 \%$ from the team-directed approach. This means that the extended strategy would be clinically relevant if it would result in an improvement of compliance with $25 \%$ of all occasions for hand hygiene. Calculating from $80 \%$ power, two-sided alpha $=0.05$, a ward-ICC of 0.05 and a nurse-ICC of 0.6 , in each of the 60 wards in the study an average of 50 observations of occasions for hand hygiene compliance are needed at each point in time, involving 15 nurses per ward.

\section{Effect evaluation: team climate}

As the extended strategy will target social interaction in teams of nurses, it is assumed that team climate will be affected in wards receiving this strategy, and not in 
wards receiving the state-of-the-art strategy. Team climate will be assessed at $\mathrm{T} 2$ and $\mathrm{T} 3$, in half of the nurses from each ward. For this purpose, the Team Climate Inventory (TCI) will be used [34]. The TCI includes 44 items on the dimensions 'participation safety,' 'task orientation,' support for innovation' and 'interaction.'

\section{Economic evaluation: costs and health effects}

Costs of infections are high, and hand hygiene is a proven effective measure in reducing infections. Therefore, strategies that focus on and result in increasing compliance to hand hygiene guidelines are likely to be costeffective. The economic evaluation will compare the two implementation strategies as described earlier in this paper both in terms of implementation costs and health effects. The aim of this evaluation is to detect which of the implementation strategies is the most cost-effective strategy for improving hand hygiene compliance and reducing HAIs. This results in two incremental costeffectiveness ratios-cost per percentage gained compliance and cost per percentage HAI prevented.

\section{Data collection}

The resources consumed by the implementation strategies will be assessed by collecting data on personnel (hours for the strategy delivery team, hours for the nurses attending the strategy related activities, extra time for hand hygiene), and materials (posters, improved products and facilities, use of hand-rub solution). These volumes will be multiplied by their unit prices (market prices, guideline prices or self-determined prices based on costing methods, i.e., full costing [35]. The cost estimate for a hospital acquired infection and additional healthcare costs will be based on previous estimates of $€ 4386$ euro per infection [36].

\section{Statistical analysis}

The implementation process and consequent costs will be estimated by an Activity Based Costing (ABC) approach. The $\mathrm{ABC}$ model focuses on identifying all the underlying activities (personnel, material and overhead costs) associated with the state-of-the-art strategy and the extended strategy.

The health effects of the implementation strategies for reducing hospital-acquired infections will be analyzed using decision analysis. We assume a baseline prevalence of infection of $6.6 \%$, based on the data from The PREZIES national network for the surveillance of HAIs in The Netherlands [37]. With regard to the association between infection rates and hand hygiene compliance rates, a pooled (if possible) estimation will be applied. For this purpose, we will perform a review of the literature, using systematic review methodology, to identify studies that report of the impact of hand hygiene on
HAIs. Studies should at least include outcome comparison with a (randomized or non randomized) comparison group, or a comparison with baseline data in case of a single group pre-test post-test design. Studies will be further selected if they satisfy the following conditions:

1. Population: healthcare workers in hospital settings.

2. Intervention: strategies or programmes aimed at improving hand hygiene behaviour.

3. Comparison: hand hygiene behaviour and infection rates.

a. Hand hygiene behaviour prior to the introduction of the program or strategy.

b. Infection rates in health-care settings prior to the introduction of the program or strategy.

4. Outcome: hand hygiene behaviour and infection rates.

a. All operationalisations of hand hygiene behaviour in healthcare workers.

b. Infection rates in healthcare setting.

\section{Systematic evaluation of implementation fidelity}

In trials on the effects of implementation strategies, a process evaluation can shed light on the target group members' actual exposure to the strategy [38]. In this manner, insight is gained into potential determinants of success or failure of the strategies. This step also will aid in replicating the strategy in future research. For this purpose, process data will be gathered for each of the activities within the state-of-the-art strategy and the extended strategy.

\section{State-of-the-art strategy}

Participation in education will be assessed by measuring the number of nurses that completed the knowledge quiz and by monitoring the presence of instruction leaflets on the ward. Use of reminders will be checked by measuring the presence of reminders (posters) at random moments during the strategy delivery period. Whether performance feedback was provided will be assessed by measuring the extent to which the ward manager provided feedback to the nurses. In addition, the extent to which products and facilities were available will be checked by measuring the presence of products and facilities in each ward.

\section{Extended strategy}

The use of coaching of either ward management or informal leaders will be assessed by measuring the number of coaching sessions, the total time spent on coaching, and the topics covered during the session. The use 
of organised team discussions for norm and target setting will be checked by measuring the number of team discussions performed, the number of nurses attending per ward, the time investment per ward, and the actual norms and targets decided on. Process evaluation data will be collected using a combination of data-collection methods, including questionnaires, direct observations, and systematic registration of time and meeting minutes. For each of the elements of the strategies 'actual exposure' to the strategy element at the level of wards will be coded as 'low,' 'moderate' or 'high' based on the process indicator data collection. Relations between strategy exposure and hand hygiene compliance after the delivery of the strategies will be explored.

\section{Evaluation of barriers and ward structure}

Previous recommendations from literature have pointed out that an improvement strategy for hand hygiene behaviour should address existing problems and barriers $[21,39,40]$. Grol and Grimshaw studied the failing implementation of evidence on hand hygiene in the healthcare setting and identified a variety of barriers to change, including a lack of awareness, knowledge, reinforcement, control, social norms, leadership, and facilities [15]. In our study, these identified barriers to change will be targeted by either the state-of-the-art strategy or the extended strategy. The presence of barriers will be investigated twice-before and after strategy delivery-using a questionnaire in one-half of the nurses from each ward. The barrier questionnaire contains 47 different propositions concerning 21 barriers.

To collect information about existing structures and resources, such as actual presence of facilities, workload, nurse-bed ratio, understaffing, and support from the management, a questionnaire on ward structure will be administered twice to every ward manager.

\section{Ethical and legal aspects}

The Medical Ethics Committee of district Arnhem-Nijmegen assessed the study and concluded that our study was deemed exempt from their approval because it did not include collection of data at the level of patients.

The Hawthorne effect is probably the most important bias in hand hygiene observations $[1,30,33,41]$. Persons who know they are being observed change their behaviour and are significantly more likely to wash or disinfect their hands. Unobtrusive observation diminishes the Hawthorne effect, but raises ethical questions regarding privacy of the observed participants. Therefore, we consulted the ethical committee. They concluded that unobtrusive observation will be permitted under the following conditions: the observation topic, hand hygiene, will be covered by using general patient safety issues as subject of the observation; the observations on the nurses should be collected and processed anonymously; and prior to the observation, the patient has given verbal permission to observe.

\section{Discussion}

Changes in healthcare can target individual professionals, teams and units, or healthcare organisations [15]. Traditionally, implementation strategies are directed at individual professionals (individual level) or address structural work context (organisational level), whereas team-directed strategies are rarely studied. The unique contribution of the extended strategy was built upon social learning theory, Social influence theory [23], theory on team effectiveness $[20,20,25,25,26,26]$ and leadership theory [24]. Together, these theories provide a coherent set of methods to target the social context in which hand hygiene behaviour takes place. Because targeting social context is not often employed in implementation strategies, the results of our project will considerably add to the general body of knowledge by evaluation of the added value of the extended strategy as compared to the state-of-the-art strategy.

Results from our study will allow us to draw conclusions on the effects of different strategies for the implementation of hand hygiene guidelines, and based on these results we will be able to define a preferred implementation strategy for hospital-based nursing. Our evaluation of the state-of-the-art strategy will validate the effectiveness of this strategy in Dutch hospital care. The evaluation will further provide a longer term follow-up effect estimate, whereas commonly only effects during or directly after strategy delivery are evaluated $[15,16]$.

We believe our study has methodological strengths because of the large numbers of observations and participating wards, the randomisation of wards either to the state-of-the-art strategy or the extended strategy, and the use of unobtrusive observations.

We anticipate several challenges in conducting this study. First, in an ideal world, one would choose randomisation of wards or teams to three groups: a state-ofthe-art strategy group, an extended strategy group, and a no strategy group. However, as the state-of-the-art strategy includes hospital-wide campaign elements (e.g., posters on doors, instruction leaflets, and short articles in hospital magazines), three-group randomisation at the level of wards would certainly introduce contamination of the no strategy group. This implies that threegroup randomisation in the same hospital is not a feasible option. We will collect baseline data twice, with a six month interval, in order to create a reference period with no strategy. Second, timely and accurate data collection for this study is also challenging. To ensure that comprehensive data collection is feasible in all participating hospitals, we will partner with an established 
Faculty of Health and Social Studies in recruiting, training, and assessing the students who will perform the observations.

Third, in this study we will not measure nosocomial infections. Measuring nosocomial infections on ward level and correcting for all possible interference from other factors would be labour intensive and costly. Given the fact that the relationship between hand hygiene and the occurrence of infections already is well established, and given practical difficulties in achieving comparable patient groups with regard to risk factor and scoring patients who transfer between wards, we decided to use a model-based estimate of HAIs.

Finally, we will not measure compliance in physicians or other healthcare workers. The main reason for not including physicians is the difference in team structure and teamwork between nurses and physicians. Whereas hospital nurses typically work and interact in wardbased teams, physicians more often work independently and on various locations. Targeting physician-directed social influence would ask for strategies other than targeting nurse-directed social influence. Nevertheless, the state-of-the-art strategy is visible to all hospital staff, and may affect physicians' hand hygiene as well.

We believe that by performing this study, we will improve hand hygiene behaviour and contribute to the body of knowledge on effective strategies for implementing hand hygiene guidelines in healthcare settings. We will specifically add knowledge to the social influence based implementation activities.

\section{Source of funding}

This study is funded by a research grant from ZonMw, dossier number: 94517101.

\section{Additional material}

Additional file 1: Hand Hygiene Monitoring Tool. Scoreform Hand Hygiene opportunities.

\begin{abstract}
Authors' contributions
TVA, LS, and MH were responsible for the research question and designed the study. RG, EA, and GB commented on the design. AH wrote the first draft of this manuscript and was responsible for the revisions. TVA, LS, RG, and $\mathrm{MH}$ contributed to drafting of the manuscript. GB is the statistician and performed the power calculation, the sample size considerations, and offered advice on the statistical analysis. EA is the team's expert in economic evaluations and was involved in the design of the study. TVA is the general supervisor of the study and was involved in revising the article. All authors read and approved the final version of the manuscript.
\end{abstract}

\section{Competing interests}

The authors declare that they have no competing interests.

Received: 12 April 2011 Accepted: 3 September 2011 Published: 3 September 2011
References

1. Pittet D, Hugonnet S, Harbarth S, Mourouga P, Sauvan V, Touveneau S, et al: Effectiveness of a hospital-wide programme to improve compliance with hand hygiene. Infection Control Programme. Lancet 2000, 356:1307-1312

2. World Health Organization: The first Global Patient Safety Challenge: Clean Care is Safer Care.[http://www.who.int/gpsc/en/].

3. Lucet JC, Rigaud MP, Mentre F, Kassis N, Deblangy C, Andremont A, et al: Hand contamination before and after different hand hygiene techniques: a randomized clinical trial. J Hosp Infect 2002, 50:276-280.

4. Pittet D, Dharan S, Touveneau S, Sauvan V, Perneger TV: Bacterial contamination of the hands of hospital staff during routine patient care. Arch Intern Med 1999, 159:821-826.

5. Day M: Chief medical officer names hand hygiene and organ donation as public health priorities. BMJ 2007, 335:113.

6. Donaldson L: Dirty hands...the human cost London: UK Department of public health; 2006.

7. Larson E: A causal link between handwashing and risk of infection? Examination of the evidence. Infect Control Hosp Epidemiol 1988, 9:28-36.

8. Larson EL: APIC guideline for handwashing and hand antisepsis in healthcare settings. Am J Infect Control 1995, 23:251-269.

9. Lautenbach E: Practices to Improve Handwashing Compliance. In Making healthcare safer: a critical analysis of patient safety practices. Edited by: Shojania K, Duncan B, MacDonald K, Wachter R. Rockville, MD: Agency for Healthcare Research and Quality; 2001:125-131.

10. Pittet D, Allegranzi B, Sax H, Dharan S, Pessoa-Silva CL, Donaldson L, et al: Evidence-based model for hand transmission during patient care and the role of improved practices. Lancet Infect Dis 2006, 6:641-652.

11. Teare E, Cookson B, French G: Hand washing-a modest measure with big effects. BMJ 1999, 318:686.

12. Kuzu N, Ozer F, Aydemir S, Yalcin AN, Zencir M: Compliance with hand hygiene and glove use in a university-affiliated hospital. Infect Control Hosp Epidemiol 2005, 26:312-315.

13. Pittet $D$, Mourouga $P$, Perneger TV: Compliance with handwashing in a teaching hospital. Infection Control Program. Ann Intern Med 1999, 130:126-130.

14. Pittet D: Improving compliance with hand hygiene in hospitals. Infect Control Hosp Epidemiol 2000, 21:381-386.

15. Grol R, Grimshaw J: From best evidence to best practice: effective implementation of change in patients' care. Lancet 2003, 362:1225-1230.

16. Naikoba S, Hayward A: The effectiveness of interventions aimed at increasing handwashing in healthcare workers - a systematic review. $J$ Hosp Infect 2001, 47:173-180.

17. Grimshaw J, Eccles M, Thomas R, MacLennan G, Ramsay C, Fraser C, et al: Toward evidence-based quality improvement. Evidence (and its limitations) of the effectiveness of guideline dissemination and implementation strategies 1966-1998. J Gen Intern Med 2006, 21(Suppl 2): S14-S20.

18. Bandura A: Social foundation and thought of action: a social cognitive theory New York: Prentice Hall; 1986.

19. Bosch M, Faber MJ, Cruijsberg J, Voerman GE, Leatherman S, Grol RP, et al: Review article: Effectiveness of patient care teams and the role of clinical expertise and coordination: a literature review. Med Care Res Rev 2009, 66:5S-35S.

20. Firth-Cozens J: Celebrating teamwork. Qual Healthcare 1998, 7(Suppl): S3-S7.

21. Grol R, Wensing M: Effective implementation: A model. In Improving patient care: The implementation of change in clinical practice. Edited by: Grol R, Wensing M, Eccles M. London: Elsevier; 2005:41-57.

22. Larson EL, Early E, Cloonan P, Sugrue S, Parides M: An organizational climate intervention associated with increased handwashing and decreased nosocomial infections. Behav Med 2000, 26:14-22.

23. Mittman BS, Tonesk $X$, Jacobson PD: Implementing clinical practice guidelines: social influence strategies and practitioner behavior change. QRB Qual Rev Bull 1992, 18:413-422.

24. Øvretveit J: The Leaders' Role in Quality and Safety Improvement; a review of Re-search and Guidance; the 'Improving Improvement Action Evaluation Project Stockholm: Association of County Councils (Lanstingsforbundet); 2004.

25. Shortell SM, Marsteller JA, Lin M, Pearson ML, WU SY, Mendel P, et al: The role of perceived team effectiveness in improving chronic illness care. Med Care 2004, 42:1040-1048. 
26. West MA: The social psychology of innovation in groups. In Innovation and creativity at work: Psychological and Organizational Strategies. Edited by: West MA, FJl. Chichester: John Wiley and Sons; 1990:309-333.

27. Campbell MC, Elbourne D, Altman D: CONSORT statement: extension to cluster randomised trials. BMJ 2004, 328:702-708.

28. Eccles M, Grimshaw J, Campbell M, Ramsay C: Research designs for studies evaluating the effectiveness of change and improvement strategies. Qual Saf Healthcare 2003, 12:47-52.

29. Werkgroep Infectiepreventie: Handhygiëne medewerkers ziekenhuizen. [http://www.wip.nl/free_content/Richtlijnen/ Handhygiene_medewerkers_071015def.pdf].

30. World Health Organization: WHO Guidelines on Hand Hygiene in Healthcare First Global Patient Safety Challenge: Clean Care is Safer Care.[http://whqlibdoc.who.int/publications/2009/9789241597906_eng.pdf].

31. Boyce JM: Hand hygiene compliance monitoring: current perspectives from the USA. J Hosp Infect 2008, 70(Suppl 1):2-7.

32. Braun BI, Kusek L, Larson E: Measuring adherence to hand hygiene guidelines: a field survey for examples of effective practices. Am J Infect Control 2009, 37:282-288.

33. Sax H, Allegranzi B, Chraiti MN, Boyce J, Larson E, Pittet D: The World Health Organization hand hygiene observation method. Am J Infect Control 2009, 37:827-834

34. Anderson NR WM: Measuring climate for work group innovation: development and variability of the team climate inventory. Journal of Organizational Behavior 1998, 19:235-258.

35. Oostenbrink J, Bouwmans C, Koopmanschap M, Rutten F: Handleiding voor kostenonderzoek, methoden en standaard kostprijzen voor economische evaluaties in de gezondheidszorg Diemen: College voor zorgverzekeringen; 2005.

36. Plowman R, Graves N, Griffin M, Roberts J, Swan T, Cookson B, et al: The Socio-economic burden of hospital acquired infection London: Public Health Laboratory Service; 1999.

37. Benthem van B, Kooi van der T, Hopmans T, Wille J: Trend in prevalentie van ziekenhuisinfecties in Nederland 2007-2009. Infectieziekten Bulletin 2010, 21:226-229.

38. Hulscher ME, Laurant MG, Grol RP: Process evaluation on quality improvement interventions. Qual Saf Healthcare 2003, 12:40-46.

39. Bosch M, van der WT, Wensing M, Grol R: Tailoring quality improvement interventions to identified barriers: a multiple case analysis. J Eval Clin Pract 2007, 13:161-168.

40. Grol $\mathrm{R}$, Wensing M: What drives change? Barriers to and incentives for achieving evidence-based practice. Med J Aust 2004, 180:S57-S60.

41. Eckmanns T, Bessert J, Behnke M, Gastmeier P, Ruden H: Compliance with antiseptic hand rub use in intensive care units: the Hawthorne effect. Infect Control Hosp Epidemiol 2006, 27:931-934.

doi:10.1186/1748-5908-6-101

Cite this article as: Huis et al:: Helping hands: A cluster randomised trial to evaluate the effectiveness of two different strategies for promoting hand hygiene in hospital nurses. Implementation Science 2011 6:101.

\section{Submit your next manuscript to BioMed Central and take full advantage of:}

- Convenient online submission

- Thorough peer review

- No space constraints or color figure charges

- Immediate publication on acceptance

- Inclusion in PubMed, CAS, Scopus and Google Scholar

- Research which is freely available for redistribution 